\title{
First Record and Morphological Identification of the Seahorse Hippocampus kelloggi Great Seahorse Jordan and Snyder (1902) in Coastal Waters of Pakistan
}

\author{
Noor Us Saher ${ }^{1 *}$, Mustafa Kamal ${ }^{2}$, Mansoor Rodini ${ }^{3}$, Farah Naz ${ }^{4}$ and Altaf Hussain Narejo ${ }^{1}$ \\ ${ }^{1}$ Centre of Excellence in Marine Biology (CEMB), University of Karachi, Pakistan \\ ${ }^{2}$ Department of Zoology, University of Karachi, Pakistan \\ ${ }^{3}$ Lasbela University of Agriculture, Water and Marine Sciences (LUAWMS), Pakistan \\ ${ }^{4}$ Institute of Marine Sciences (IMS), University of Karachi (UOK), Pakistan
}

Submission: January 04, 2021; Published: March 03, 2021

Corresponding author: Noor Us Saher, Centre of Excellence in Marine Biology (CEMB), University of Karachi, Pakistan

\begin{abstract}
The first record of seahorse Hippocampus kelloggi commonly known as the great Seahorse from the coastal waters of Pakistan based on morphological and morphometric characteristics. The Seahorses belong to family Syngnathidae and about 50 species have been reported across the world. They have been found to inhabit coral reefs, seagrass beds and also coastal mangroves. All seahorse species (Hippocampus sp.) are vulnerable and according to the global conservation status of Hippocampus kelloggi is also among them. H. kelloggi is listed as data deficient since 2003 and then classified as IUCN Red List (http://www.iucnredlist.org) Category \& Criteria: A2cd version 3.1 (2017). The Hippocampus kelloggi previously recorded from the Indo Pacific regions, including China; India; Indonesia; Japan; Malaysia; Philippines; Thailand; United Republic of Tanzania; Viet Nam. The current study confirmed the presence of $H$. kelloggi from the coastal waters of Pakistan.
\end{abstract}

Keywords: Seahorse; Syngnathidae; Hippocampus; IUCN Red List; Pakistan

\section{Introduction}

This is the first record of seahorse Hippocampus kelloggi commonly known as the great seahorse from the coastal waters of Pakistan as provide morphological identification and range extension of the species. The seahorses are representative of family Syngnathidae that includes, pipe fishes, pipe horses and sea dragons. There are about 50 species reported across the world and have been found to inhabit various home ranges, i.e., Sea grass beds, coastal mangroves, and coral reefs, although characterized as sedentary fish species with patchy distribution [1-3]. H. kelloggi previously described for the low mobility, fecundity, prolonged parental care, mate fidelity and reproduction information [4-6]. In Philippines, H. kelloggi reported at maximum depth of $152 \mathrm{~m}$ and associated morphological revisions of seahorse have been also carried out [7]. According to the morphometric characteristics, five species of Hippocampus including Hippocampus kuda (Bleeker 1852), H. fuscus (Ruppell 1838), H. trimaculatus (Leach 1814), $H$. kelloggi, and H. histrix (Kaup 1856) reside in the Indian Ocean waters [8].

All Hippocampus species are included in the IUCN Red List (http://www.iucnredlist.org). According to the IUCN Red List (2006) 20 species of seahorse designated as 'vulnerable'; 11 as 'data deficient' and one (H. capensis) designated as endangered'. H. kelloggi is listed as data deficient since 2002 by IUCN and vulnerable (VU) as assessment done in 2017 by IUCN [9]. The assessment designated $H$. kelloggi as vulnerable species in Red List Category and Criteria: A2cd ver. 3.1 in the IUCN Red List of threatened species and included in the CITES Appendix II effective in May 2004, although the H. kelloggi removed from the Australian Wildlife Protection Act in 1998 and then placed in Environment Protection and Biodiversity Conservation Act in 2001. However, according to the review of China's biodiversity reported H. kelloggi as the threatened species of China as placed in wildlife protection 
laws, while the Priority Fish species (Grade B) also included $H$. kelloggi in National Red Data book, as a vulnerable in the Viet Nam [5].

Dried seahorse used in the traditional Chinese medicine market. The trade of seahorse observed throughout its distribution range bycatch during shrimp trawling [10-13]. Whereas currently legal and illegal trade also enduring (UNEP-WCMC $2012 \mathrm{a}, \mathrm{b}$ ) that why the stock was substantially declines between 1995 and 2000 [6], in addition Singapore, United Arab Emirates and Hong Kong import 4.34 tons of sea horse from India during the year 2001$200[5,14-16]$.

According to $70 \%$ decline in Seahorse population included $H$. kelloggi $[12,15,17]$ due to the over exploitation at the Palk Bay and Gulf of Mannar in the South-east coast of India, and to overcome this issue, India Government prohibited the trade and fishing of representatives of family Syngnathidae as a protected species under the Schedule I (Part 2A) of the Indian Wildlife (Protection) Act, 1972 through a Notification No. 1-4/95 WL1 dated 11 July, 2001, [12,15], UNEP-WCMC 2012b. Molecular identification of dried seahorse and pipe fish was done, that was sold on the Chinese market by using two mitochondrial COI and $16 S$ rRNA genes and revealed the exploitation of representatives of family Syngnathids by illegal and not regulated trade. Previously, there is no record of sea horse species from the coastal water of Pakistan, the current study provides the evidence for the presence and range extension of $H$. kelloggi from the coastal water of Pakistan $[18,19]$.

\section{Hippocampus kelloggi Jordan and Snyder 1902}

\section{Common names}

Kellogg's Seahorse, Great Seahorse (U.S.A.), Offshore Seahorse (Viet Nam), O-umi-uma (Japanese; Japan)

\section{Synonyms}

H. suezensis Duncker (1940)

\section{Systematics}

Actinopterygii (ray-finned fishes)

Syngnathiformes (Pipefishes and seahorses)

Syngnathidae (Pipefishes and seahorses)

Hippocampinae

\section{Etymology}

Hippocampus: Greek, Ippos = horse; Greek, kampe = curvature

\section{Colour/pattern}

Greenish brown in color.

\section{Confirmed distribution}

According to [18] distributed throughout the Indo Pacific region, including China; India; Indonesia; Japan; Malaysia; Pakistan; Philippines; Thailand; United Republic of Tanzania; Viet Nam (Figure 1).

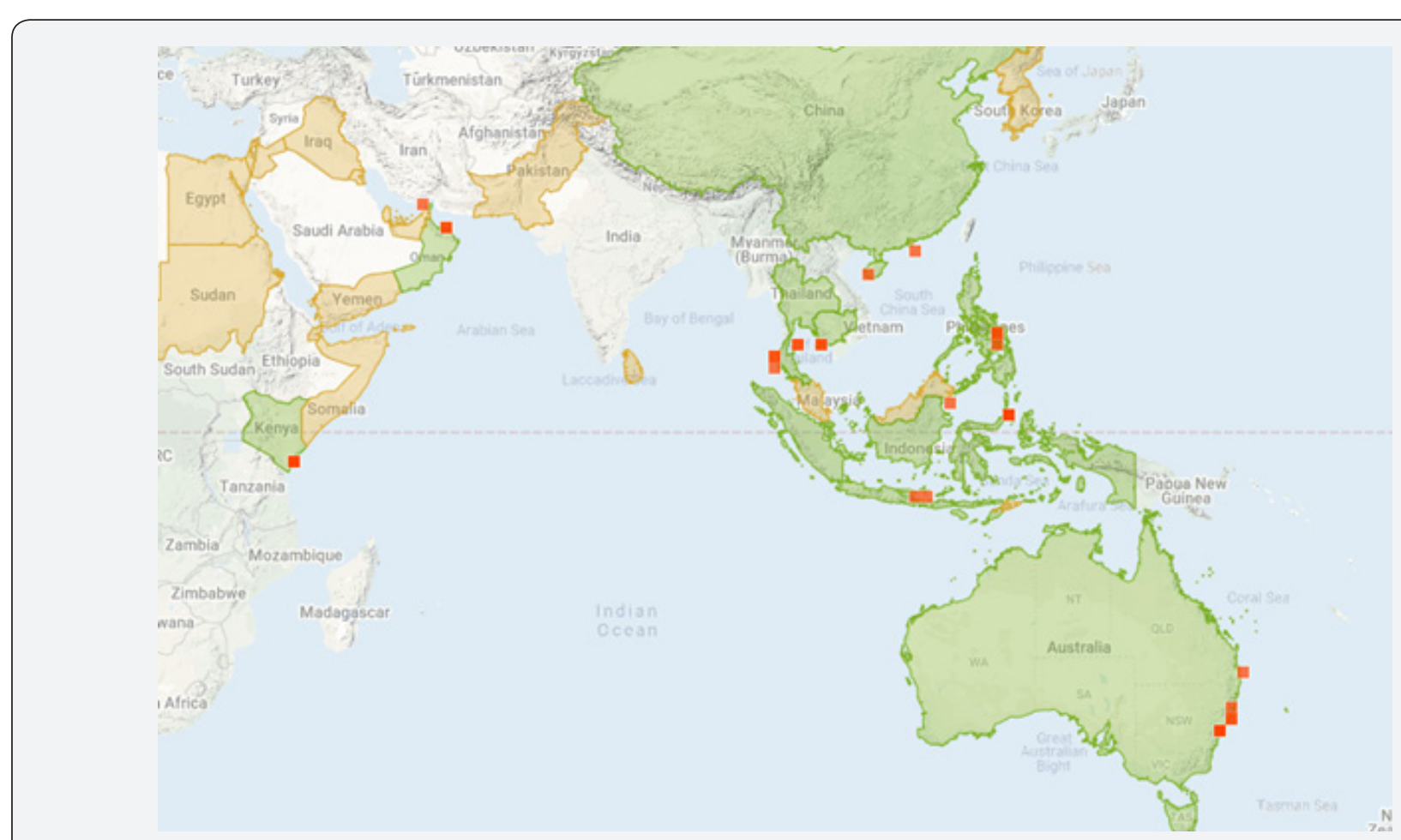

Figure 1: Distribution range of $H$. kelloggi Ref: I Naturalist September 2019. 


\section{Habitat}

Maximum reported depth $152 \mathrm{~m}$; associated with gorgonian corals and sea whips; soft bottom Microalgae on rocky reefs. Seashores are found in temperature and tropical coastal waters, coral reefs, and seagrass beds.

\section{Economic Importance}

Dried for traditional medicine and curios, live for aquarium and hobbyist use.

\section{Vulnerability}

Red List Category \& Criteria: Vulnerable A2cd ver 3.1 (2017)

Red List Vulnerable (VU) (2012)

http: / / dx.doi.org/10.2305/IUCN.UK.2012.RLTS. T41010A17242053.en Data Deficient (DD) (2002). (Table 1).

Table 1: Conservation status.

\begin{tabular}{|c|c|}
\hline $\begin{array}{c}\text { CITES } \\
\text { IUCN }\end{array}$ & $\begin{array}{c}\text { Appendix II effective May 2004 } \\
\text { Data deficient }\end{array}$ \\
\hline Australian Wildlife Protection Act & Removed in1998 \\
\hline Environment Protection and Biodiversity Conservation Act & Placed in 2001 \\
\hline Wildlife Protection Laws & Priority Fish species (Grade B) Review of China's biodiversity \\
\hline National Red Data Book & Vulnerable in the Viet Nam \\
\hline
\end{tabular}

\section{Morphological Identification and Morphometric Measurements}

The description of the seahorse was made based on the observation of a single specimen which was caught in a rock pool at Mubarak village, rocky cum sandy shore found in the rocky pool at a depth of four feet, from the coastal waters of Pakistan (Figure 2), on dated $18^{\text {th }}$ April 2019. Morphological identification based on the taxonomic characters and all Morpho-measurements were made according to the standard protocol. Length of specimen is given as standard length (from the tip of snout to end of the tail) up to the nearest $0.1 \mathrm{~mm}$. The comparison of morphometric and meristic character was made based on the earlier literature [7]. Later the Morphometric characters were examined and compared with earlier observations (Table 2). As per earlier description, this species shares the characters similar to the Hippocampus spinosissimus with the presence of distinct high coronet and with five short spines.

Table 2: Morphological Measurements of H. kelloggi.

\begin{tabular}{|c|c|c|}
\hline & Morphological variables & Measurements \\
\hline 1 & Cheek spines (CS) & Prominent slightly backward Pointing cheek spines \\
\hline 2 & Cleithral ring & high with five short spines \\
\hline 3 & Coronet & Prominent Eye Spines \\
\hline 4 & Dorsal fin rays & $2 \mathrm{~cm}$ \\
\hline 5 & Eye spines (ES) & $9.9 \mathrm{~cm}$ \\
\hline 6 & Head length (HL) & yes \\
\hline 7 & Height (Ht) & yes \\
\hline 8 & Nose spine & 17 \\
\hline 9 & Operculum & $0.8 \mathrm{~cm}$ \\
\hline 10 & Pectoral fin rays & $6.4 \mathrm{~cm}$ \\
\hline 11 & Snout length (SnL) & 39 rings \\
\hline 12 & Tail length & $2.6 \mathrm{~cm}$ \\
\hline 13 & Tail rings (TaR) & 11 \\
\hline 14 & Trunk length & 2 Trunk rings, 1 Tail ring \\
\hline 15 & Trunk rings (TrR) & Yes \\
\hline 16 & Rings supporting dorsal fin & \\
\hline 17 & Anal fin & \\
\hline
\end{tabular}



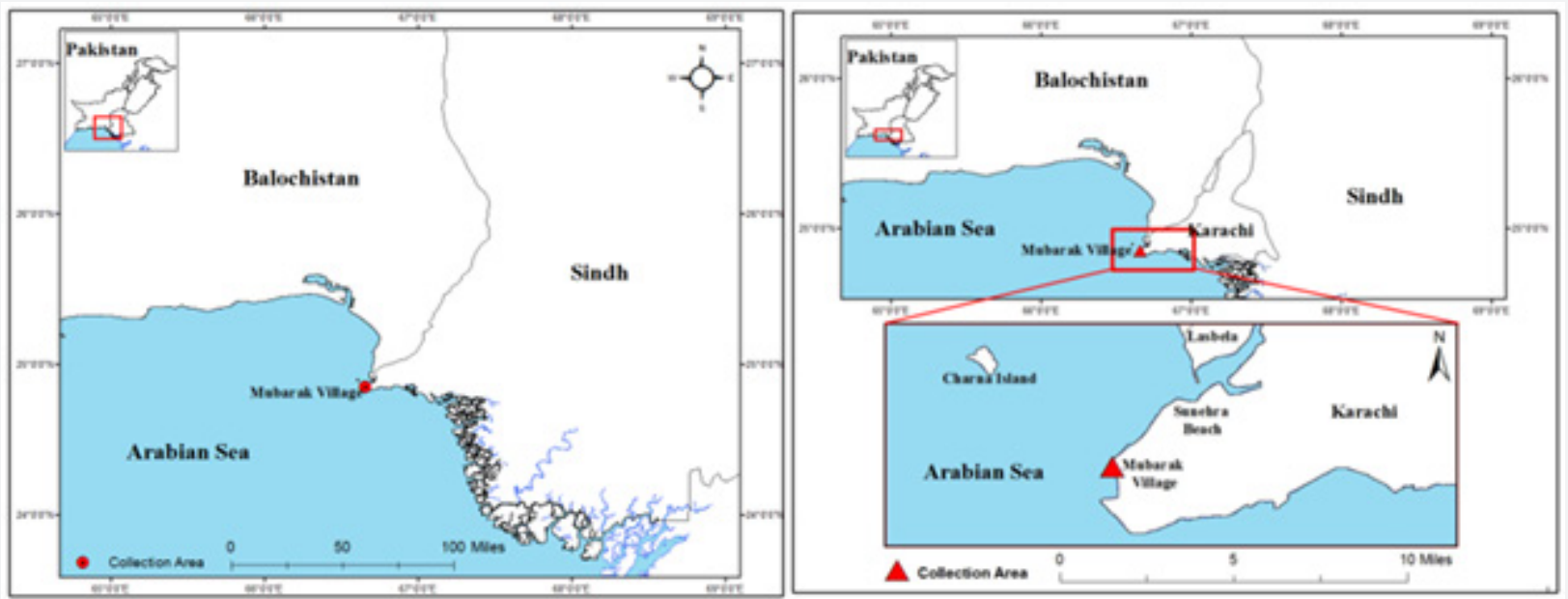

Figure 2: Map of the occurrence (Mubarak village) of $\mathrm{H}$. kelloggi from the coastal waters of Pakistan.

\section{Diagnostic characteristics (Figure 3 \& 4).}

Seahorse species have elongated body encased in thick trunk rings, back-pointing, small pectoral fins and a single dorsal fin, thick snout with no teeth, maximum recorded height is $28 \mathrm{~cm}$, with tiny white spots running in vertical lines. Body narrows with thick snout (tube like), deep head. The species characterized by the distinct high coronet, with five short spines with high plate in front of coronet and a prominent rounded eye spine. They have long, slightly backward pointing, rounded cheek spine. Spines low and rounded; slightly better developed in younger specimens, but still blunt tipped. Other distinctive characteristics: Long, slightly backwards-pointing, rounded cheek spine; deep head; narrow body; thick body rings; prominent, rounded eye spine; thick snout.

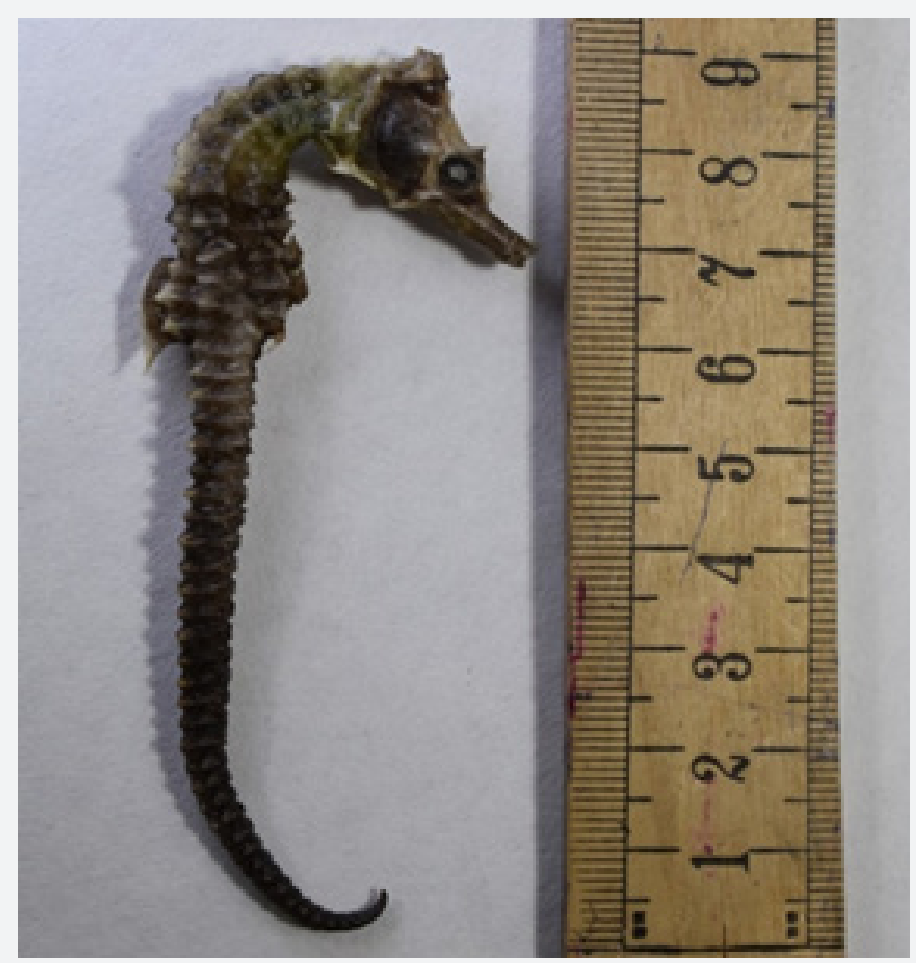

Figure 3: Lateral view of complete specimen of $H$. kelloggi. 
A.
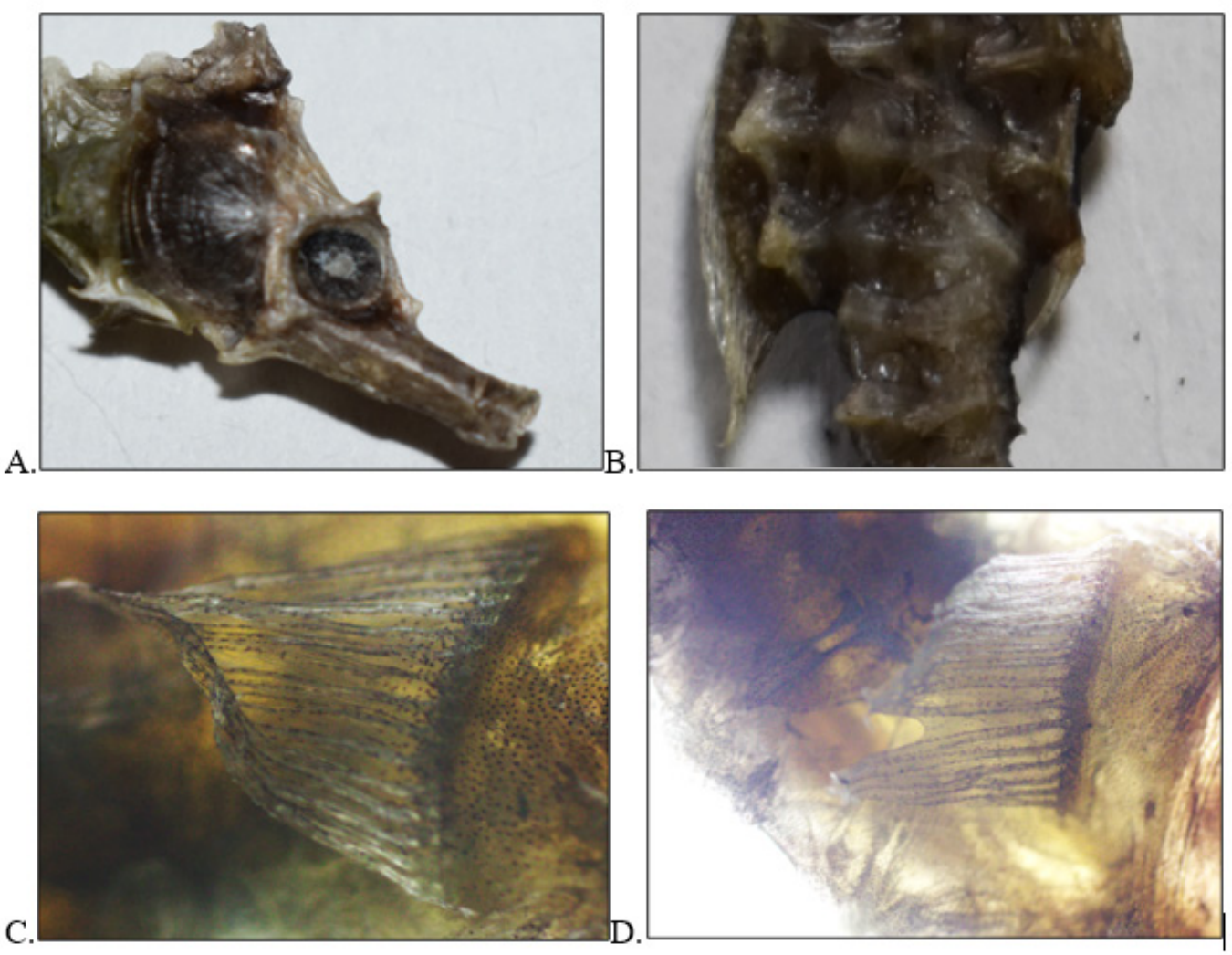

Figure 4. Description of some morphological characters of $H$. kelloggi (A): Head dorsal view (B): Rings Supporting the Dorsal Fin (C): Pectoral fin (D): Dorsal fin.

\section{Taxonomic Remarks}

According to literature [5], Pakistan included in the distribution range of $H$. kelloggi however, there is no previous record of $H$. kelloggi from the coastal waters of Pakistan, the current study is the first detailed study and describe the range extension of $H$. kelloggi.

\section{Molecular Study}

\section{SDS and Native PAGE (Polyacrylamide gel electrophoresis) of General protein (GP) EC (non- specific)}

Seahorses are economical, commercially important and traded internationally, used in traditional Chinese medicine and its derivatives for the treatment includes: the respiratory disorders (asthma), sexual dysfunctions (Erectile dysfunction), and general lethargy due to the insufficient sleep, overexertion, overburdening, stress, lack of exercise, improper nutrition, boredom, and pains [10]. During the present study, an estimation was made for the various size of proteins by using the electrophoresis technique. Two types of electrophoresis were performed, SDS for general protein and Native PAGE for the specific protein (specific protein by using the specific subtract of enzyme). SDS and NativePAGE (Polyacrylamide gel electrophoresis) of General protein (GP) EC (non-specific) banding pattern was estimated in muscle tissue of K. kelloggi. Approximely 250-300 mg was removed and homogenized in $1 \mathrm{ml}$ of Tris Citrate II extraction buffer, and the sample was centrifuged at 15,000 rpm for 15 minues, supernatant was used as protein source.

Electrophoresis was performed [20] accordingly, whereas the gel was stained (Coomassie Brilliant Blue) for General protein (GP) EC (non-specific), Bovine (BSA serum albumen) used as standard protein. Electrophoresis was performed in vertical native polyacrylamide gels (Native-PAGE) as described by [20]. A total of four protein bands were observed in SDS PAGE electrophoreis (Figure 5), the Rf values ranges from 0.08 to 0.451 , the standard band ( 5 KDa standard of BSA) was observed in between gel that showed that the higher and lower molecular weight protein was observed in $H$. kelloggi sample whereas a total of five protein bands were observed in Native PAGE electrophoresis (Figure 5), the Rf values ranges from 0.098 to 0.633 . The further detailed biochemical study and characterization of protien can reveal some intresting results from these species. 


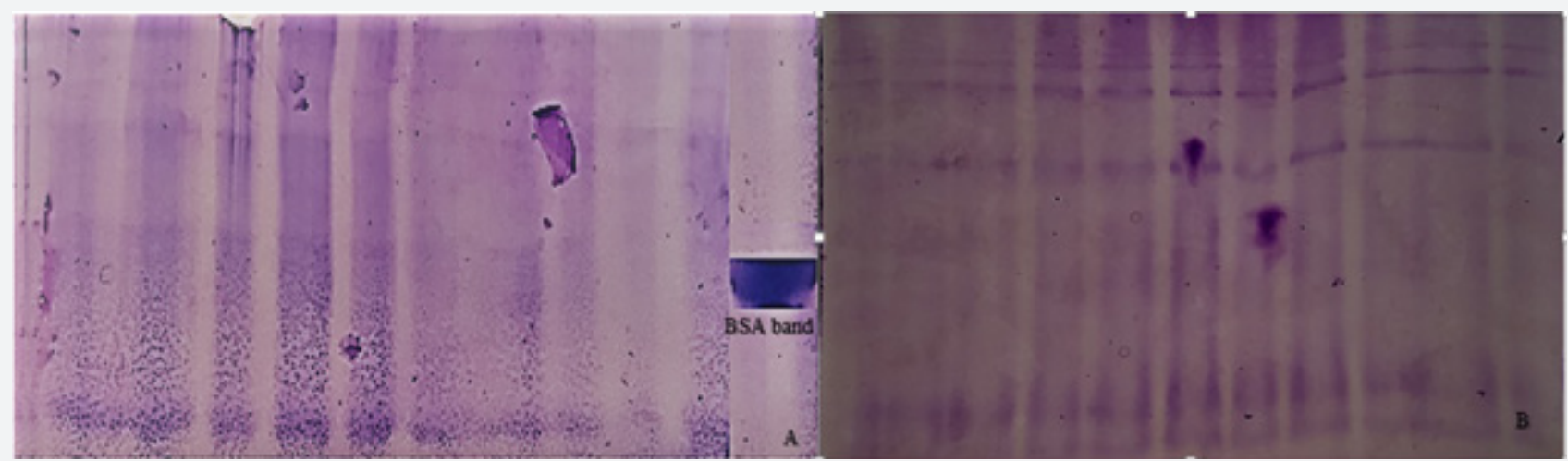

Figure 5: SDS (A) and Native PAGE (B) (Polyacrylamide gel electrophoresis) of General protein (GP) EC (non-specific) banding pattern of $H$. kelloggi.

\section{References}

1. Curtis JMR, ACJ Vincent (2006) Life history of an unusual marine fish: survival, growth and movement patterns of Hippocampus guttulatus Cuvier 1829. Journal of Fish Biology 68(3): 707-733.

2. Caldwell IR, ACJ Vincent (2013) A sedentary fish on the move: effects of displacement on long-snouted seahorse (Hippocampus guttulatus Cuvier) movement and habitat use. Environmental Biology of Fishes 96: 67-75

3. Qin G, C Johnson, Y Zhang, H Zhang, J Yine, et al. (2018) Temperatureinduced physiological stress and reproductive characteristics of the migratory seahorse Hippocampus erectus during a thermal stress simulation. Biol Open 7(6): bio032888.

4. Foster SJ, ACJ Vincent (2004) Life history and ecology of seahorses: implications for conservation and management. Journal of Fish Biology 65(1): 1-61

5. Lourie SA, SJ Foster, EWT, Cooper, AJ Vincent (2004) A Guide to the Identification of Seahorses. Project Seahorse and TRAFFIC North America, University of British Columbia and World Wildlife Fund, Washington D.C, USA.

6. Lawson JM, SJ Foster, ACJ Vincent (2017) Low bycatch rates add up to big numbers for a genus of small fishes. Fisheries 42(1): 19-33.

7. Lourie SA, ACJ Vincent, HJ Hall (1999) Seahorses: an identification guide to the world's species and their conservation. Project Seahorse, London, P. 214.

8. Jordan DS, Snyder J0 (1901) A review of the hypostomide and lophobranchiate fishes of Japan. Proceedings of the U.S. National Museum 24(1241): 1-20.

9. Pollom R (2017) Hippocampus kelloggi. The IUCN Red List of Threatened Species 2017: e.T41010A54908593.

10. Vincent C J (1996) The International Trade in Seahorses. TRAFFIC International, Cambridge, UK.
11. McPherson JM, ACJ Vincent (2004) Assessing East African trade in seahorse species as a basis for conservation under international controls. Aquatic Conservation-Marine and Freshwater Ecosystems 14(5): 521-538.

12. Murugan A, S Dhanya, S Rajagopol, T Balasubramanian (2008) Seahorses and pipefishes of the Tamil Nadu coast. Current Science 95(2): 253-260.

13. Perry AL. Project Seahorse, Department of Biology, McGill University, 1205 Docteur Penfield Avenue, Montreal, Quebec, H3A 1B1, Canada.

14. Anon (2003a) Proposals for amendment of Appendices I and II Results. CITES Secretariat, Geneva.

15. Salin KR, TM Yohannan, C Mohanakumara (2005) Fisheries and trade of seahorses, Hippocampus spp., in southern India. Fisheries Management and Ecology 12(4): 269-273.

16. Vincent ACJ, LM Sadler (1995) Faithful pair bonds in wild seahorses, Hippocampus whitei. Animal Behaviour 50(6): 1557-1569.

17. Sreepada, R A, U M, Desai S Naik (2002) The plight of Indian sea horses: Need for conservation and management. Current Science 82 (4): 377 378.

18. LourieSA, RA Pollom,S J Foster (2016) A global revision of the Seahorses Hippocampus Rafinesque 1810 (Actinopterygii: Syngnathiformes): Taxonomy and biogeography with recommendations for further research. Zootaxa 4146(1): 1-66.

19. Zeng L, A Armani, J Wen, Daohai Chen, Juan Zhao, Xuyan Li, et al. (2019) Molecular identification of seahorse and pipefish species sold as dried seafood in China: A market-based survey to highlight the actual needs for a proper trade. Food Control (103): 175-181.

20. Laemmli UK (1970) Cleavage of structural proteins during the assembly of the head of bacteriophage T4. Nature 227: 680-685. 

(C) This work is licensed under Creative

DOI: 10.19080/OFOAJ.2021.13.555859

\section{Your next submission with Juniper Publishers} will reach you the below assets

- Quality Editorial service

- Swift Peer Review

- Reprints availability

- E-prints Service

- Manuscript Podcast for convenient understanding

- Global attainment for your research

- Manuscript accessibility in different formats ( Pdf, E-pub, Full Text, Audio)

- Unceasing customer service

Track the below URL for one-step submission https://juniperpublishers.com/online-submission.php 